\title{
Adoption of Information Technology in Public Administration: a Focus on the Organiza- tional Factors of a Brazilian Federal University
}

\section{Adoção de Tecnologia da Informação na Administração Pública: de uma Universidade Federal Brasileira}

\author{
Maria do Socorro Torres Silva \\ Universidade Federal de Campina Grande - UFCG - Brasil \\ mariatorresns@gmail.com \\ ORCID: 0000-0001-9718-3007 \\ Suzanne Érica Nóbrega Correia \\ Universidade Federal de Campina Grande - UFCG - Brasil \\ e-mail: suzanne.enc@gmail.com \\ ORCID: 0000-0003-3613-234X \\ Petruska de Araújo Machado \\ Universidade Federal de Campina Grande - UFCG - Brasil \\ petruskamachado@gmail.com \\ ORCID: 0000-0003-1107-8180 \\ Verônica Macário de Oliveira \\ Universidade Federal de Campina Grande - UFCG - Brasil \\ veronicamacario@gmail.com \\ ORCID: 0000-0003-4194-9047
}

Submetido em 16/04/2020; Aprovado em 20/05/2020.

\begin{abstract}
Objective: This study aims to analyze the influence of organizational factors in the adoption of the information system at UFCG. Methodology: This is quantitative research in which a survey at the Federal University of Campina Grande (UFCG) is carried out applying Structural Equation Modelling via R software. Results: The results confirmed the positive influence of training and top-management support on the perception of ease; of top-management support on the perception of usefulness; and the perception of usefulness on the perceived benefits of the Electronic Information System (EIS). Theoretical Contributions: This research advances in studies on information technology (IT) and its implication in Public Administration, and, as it has multidisciplinary academic support, presents contributions to practice and theory in a related way. A relevant theoretical contribution is that the results of measurements for perceived usefulness (PU) and benefits reinforce the need for a better understanding towards concepts and variables of both constructs. Such a situation open ups new opportunities for theory to understand such constructs in a mandatory context of IT. Practical contributions: For professionals, it provides subsidies for institutions adopting information systems to promote a more favorable environment for their acceptance. Once the relevance of training programs, coupled with the support of top management, has the potential to increase the perception of the quality of the system by users, and thus, greater assimilation of the benefits linked to this system, impacting its acceptance.

Keywords: Public Administration; Information Technology; IT Adoption; Structural Equation Modelling.
\end{abstract}

\section{Resumo}

Objetivo: Este estudo propõe analisar a influência de fatores organizacionais na adoção de um sistema de informação na UFCG. Metodologia: Trata-se de uma pesquisa quantitativa na qual foi aplicado um survey junto à Universidade Federal de Campina Grande (UFCG). A análise dos dados foi realizada por meio de modelagem de equações estruturais com o apoio do software R. Resultado: Os resultados confirmaram a influência positiva do treinamento e do apoio da alta gerência na percepção de facilidade; 
do apoio da alta gerência na percepção de utilidade; e da percepção de utilidade sobre os benefícios percebidos do Sistema de Informação Eletrônico (SEI). Contribuições Teóricas: Esta pesquisa avança nos estudos sobre a tecnologia da informação e sua implicação na Administração Pública, e, por ter suporte teórico multidisciplinar, apresenta contribuições para a prática e para a teoria de forma relacionada. Uma contribuição teórica relevante é que os resultados das medições para PU e benefícios reforçam a necessidade de um melhor entendimento dos conceitos e variáveis de ambos os constructos. Tal situação abre novas oportunidades para a teoria e entender a amplitude dos conceitos. Contribuições Práticas: Para os profissionais, fornece subsídios para que as instituições adotantes de sistemas de informação promovam um ambiente mais favorável à sua aceitação. Uma vez comprovada a relevância dos programas de treinamento, aliados ao apoio da alta gestão, têm o potencial de aumentar a percepção da qualidade do sistema por parte dos usuários, e assim, uma maior assimilação dos benefícios atrelados a este sistema, impactando na sua aceitação.

Palavras-chave: Administração Pública; Tecnologia da Informação; Adoção de TI; Modelagem de Equações Estruturais.

\section{Introduction}

Public Administration in Brazil has undergone several transformations since the 1970s. The weakening of the military regime, technological development, and the glaring inadequacy of the bureaucratic model to the new social demands triggered the Brazilian State Crisis in 1979, requiring a total reengineering of its activity's functions (Andion, 2012; Bresser-Pereira, 2006).

Thus, the managerial model is introduced in Brazil in 1990 as a strategy to make Public Administration more efficient and less costly, meeting the needs of the citizens (Bresser-Pereira, 2006). Managerialism seeks to achieve maximum efficiency in the provision of public services, using management tools specific to private administration (Mayne \& Zapico-Goñi, 2017; Secchi, 2009).

In this scenario, innovation was one of the primary mechanisms capable of ensuring the efficiency of Public Administration (Sinni, 2017). Its objective was to optimize the available resources, through innovative forms of management and organization, promoting more benefits to society (Moussa et al., 2018; Scupola \& Zanfei, 2016). One of these innovations refers to the use of information technology (IT) as an innovation mechanism to make the performance of Public Administration more transparent and efficient in providing services to citizens (Saab et al., 2019).

The development and use of IT in the public sector defined how the Public Administration treated technology and how it innovated and modernized the provision of services to society (Mayne \& ZapicoGoñi, 2017). This process stimulated the Public Administration to open new horizons for its modernization, increasing its capacity to respond to the different needs of stakeholders such as citizens, companies, social organizations, etc. To make the government more agile and focused on the user, the services became more flexible, since individuals started to monitor their demands with the Public Administration through information systems available on the Web.

In this context, IT is applied in Public Administration to achieve more efficiency and transparency in government processes and to offer opportunities for popular participation and channels of interaction between the State and society. Nevertheless, IT facilitates and expands the transactions, flows, and connections existing in the networks of actors who transact with the public sphere. An essential transformation of this link was the process of reintegrating functions and groups of competence among public agencies to prevent citizens from turning to various public agencies to monitor a particular process. This change helped Public Administration to function within inter-organizational networks. This demand led to the convergence of IT to enable the integration, communication, and interoperability of the various governmental bodies and information systems in a more fluid way (Avanzi et al., 2017).

An example of such a system is the Electronic Information System (EIS). EIS complies with the provisions of Presidential Decree No. 8,539 of 2015, which establishes the electronic means for carrying out administrative proceedings in the bodies and entities of the Federal Public Administration. It is a platform that allows the management of electronic documents and processes in the same virtual environment instituted to solve the problem of paper accumulation and provide more agility, the democratization of information, and integration of processes (MPDG, 2015). The EIS was implemented in 87 institutions, including the Federal University of Campina Grande (Universidade Federal de Campina Grande - UFCG), through Resolution No. 02/2016, of the Higher Chamber of Administrative-Financial 
Management of the University Council, which instituted the mandatory use of the EIS as a system process management officer.

Despite the advantages that these technological innovations can offer, their adoption in Public Administration can be problematic, due to the intrinsic characteristics of organizations in this sector. The presence of factors inherited from the bureaucratic system, such as strict submission to the legal norm, hierarchical structures, and pre-established routines (Liddle, 2013), makes it challenging to insert innovative practices, especially related to the technological field. Also, user's resistance is considered a relevant factor for the acceptance of technology (H.-W. Kim \& Kankanhalli, 2009; Laumer et al., 2016). Besides, factors such as lack of training and difficulty for users to adapt to a system contribute to its underutilization. Some challenges, added to the breadth and growth of the use of EIS in organizations, expose the relevance of research to analyse the dynamics of the adoption of these technologies in Public Administration and provide a more favourable environment for their acceptance as well.

In this context, some organizational factors are decisive to minimize the resistance of users during the implementation process of technologies (Alsoub et al., 2018; Venkatesh \& Bala, 2008). For instance, the literature highlights the relevance of training as influencing the quality of a system, in terms of increasing users' perception regarding its ease of use (Alsoub et al., 2018; Davis, 1989; Sabherwal et al., 2006; Silva, 2018). Similarly, top-management support is considered a critical success factor (Hochstein et al., 2005; Pollard \& Cater-Steel, 2009; Tan et al., 2007), not only in the technological field but in any project organizational (Young \& Poon, 2013). These factors have been widely used in the literature as external variables that positively influence the perceived usefulness (PU) and perceived ease of use (PEOU) from Technology Acceptance Model (TAM), contributing to the use of technologies (Gamage, 2019; Hussein et al., 2019; Sabherwal et al., 2006) and positively affecting users' opinions about its benefits (Silva, 2018), in different organizational contexts.

Considering such arguments, this current study aims to analyze the influence of organizational factors in the adoption of an information system at UFCG. This current study has investigated, in particular, the influence of top-management support and training on perceived benefits by EIS's users at UFCG mediated by TAM antecedents such as PU and PEOU. Methodologically, a quantitative survey was carried out with the institution's employees to identify their perception about the phenomenon. The collected data were submitted to structural equation modelling (SEM) using R software.

The next sections are structured as follows: Section 2 provides a brief discussion on topics related to the adoption of information technology in Public Administration. Then, Section 3 presents the research model and hypotheses. Sections 4 and 5 describe, respectively, the research methodology, as well as showing the analyses and interpretations of the results. Finally, Section 6 discusses final considerations, theoretical and practical contributions, as well as research limitations and suggestions for future research.

\section{Theoretical Background}

This study is broadly motivated by two key aspects: the benefits and challenges of information technology for public administration and its adoption process.

\subsection{Benefits and challenges of information technology for Public Administration}

The management trend that guides innovation in Public Administration is the expansion of the use of information technology as a means of promoting the efficiency of public services (Bertot et al., 2012; Borins, 2001; Saab et al., 2019). In this way, its use allows new forms of social participation in the management of resources, giving greater legitimacy to public policies for the benefit of effectiveness, responsiveness, transparency, and governance (Edimara Mezzomo Luciano et al., 2018; Saab et al., 2018). In this context, IT becomes one of the main drivers of innovation in the public sector, offering new services such as issuing online certificates, consulting information of an individual or collective interest, monitoring of online processes, "digital" service stations, among others (Koch \& Hauknes, 2005; Von Haldenwang, 2004).

In order to make the government more agile and focused on the user, services become more flexible, once the citizen starts to monitor their demands with the public administration through information systems available on the Web. One of the most significant examples of the use of IT to improve service to citizens is the transition from the administrative process from the physical to the electronic 
environment (Osborne, 2010). The administrative process is an instrument that formalizes the ordered sequence of acts and activities of the State and individuals to produce a final will from the Administration (Van Ryzin, 2015).

Public Administration adopts the electronic process to minimize the negative impacts of physical processes. In this new view, all the procedural documents (petitions, certificates, orders, etc.) are virtual, which means that they were created internally in the system or digitized in files for viewing by electronic means (MJSP, 2019). In October 2015, Presidential Decree No. 8,539 stipulated two years, counting from the date of its publication, so that the bodies and entities of the (Brazilian) Federal Direct, Autarchic, and Foundational Public Administration use the electronic means in activities related to administrative processes.

As a platform for processing electronic processes, the Federal Regional Court of the 4th Region created the Electronic Information System (EIS). EIS is an electronic document and process management system that eliminates the use of paper as physical support for institutional records, also allowing the sharing of information and the communication of new events in real-time (MPDG, 2015). In this way, EIS emerges as an innovative alternative for solving problems related to the accumulation of physical documents, bringing, theoretically, more agility in the dissemination of information. Despite the benefits, the adoption of the EIS can also bring some challenges and adverse effects. Some negative effects are related to the slow adaptation on the part of the users to a large number of resources and tools offered by the system, which, added to an ineffective training course, causes slowness and confusion in the initial use (Nascimento, 2017).

Other aspects may hamper the use of these technologies in Public Administration. For example, the scarcity of resources and personnel, budget constraints, change of government, and volatility of the strategy (Bhattacherjee \& Premkumar, 2004; Liddle, 2013). Besides these particularities, the approach of these systems and their assimilation in the public sector have contributed positively to a cultural change, replacing a bureaucratic model with a more organic model and offering open structures. Also, such systems have allowed the replacement of a fragmented management model for a more integrative and collaborative approach.

\subsection{Theoretical Constructs for the Adoption of Information Technology in Public Administration}

Public Administration incorporated IT into its activities due to its ability to improve the efficiency of services, generate savings for the State, expand transparency, and provide more quality in meeting citizen's demands. In this way, they connect public organizations and other actors as well as facilitating the co-production of their services (Cordella \& Paletti, 2818; Oliveira et al., 2015). Due to this, use of IT in governments has been considered a driver of social, economic, and political changes. As a result, new models of the relationship between the State and society are emerging. Thus, IT governance models have been adopted in public organizations, presenting aspects to verify the adequacy of the guide in a given context (Rusu \& Viscusi, 2017).

The models of IT governance in public organizations present essential aspects for their implementation (Luciano et al., 2017). Reis and Neto (2019) present that critical success factors in the implementation of information technology governance (ITG) in the Brazilian federal public administration, namely top management, should continually support deployment. It means the implementation of ITG must be decided by senior management, aligning IT with business. Besides, it must offer an efficient communication and cooperation between stakeholders; identify and engage critical stakeholders; have a strategic dimension for IT resources management in the organization; retain key people for deployment; empower IT staff to embrace change; monitor legal compliance; and so on.

Thereby, the synthetic success factors serve to help the government organization in its information system planning process (Napitupulu \& Sensuse, 2014). These comprehensive models substantially improve the understanding of the adoption of organizational innovation. By identifying the relevant factors, sub-factors, and their interrelations, they can better serve and guide professionals, managers, and entities in direct contact with the organizational infrastructure within government organizations, initiating and implementing innovations successfully and effectively (Alreemy et al., 2016; Kamal, 2006).

However, adopting this type of tool leads public organizations to face some difficulties, as the use of IT implies the need to adapt to new work practices (Cunha et al., 2011). In mandatory contexts, the 
use of technological tools presents a high level of complexity. Thus, the system must be adapted to the needs of users to positively impact their satisfaction (Hsieh et al., 2011).

In this context, for the adoption of information technology to be successful, it is necessary to consider factors such as the characteristics of the institutional context and the user's profile. Once technological problems represent less than $5 \%$ of failures in the adoption of IT. At the same time, psychological aspects related to the resistance to the implementation of IT are considered fundamental barriers for a valid adoption (Rizzuto et al., 2014).

Considering the application of IT in the Brazilian context, specifically, the adoption and acceptance of the electronic process in public organizations, Silva (2018) propose a conceptual model, based on facilitating factors and system benefits perceived by users to facilitate the adoption of IT. In the current research model, training and top-management support facilitate the adoption of systems in organizations. Besides, the Technology Acceptance Model (TAM) predicts that these external variables can affect perceived usefulness (PU) and perceived ease of use (PEOU) in adopting technology in organizations (Davis, 1989).

Training refers to the individual's ability to use a specific system (Sabherwal et al., 2006). Studies point to practice as a relevant item for increasing the acceptance of technology by users since the creation of an efficient training program minimizes the resistance caused by the unfamiliarity with a given information system (Boothby et al., 2010). Top-management support refers to the degree to which management actively supports the adoption and diffusion of a technology (Bueno \& Salmeron, 2008), either a favourable attitude of top management towards the system (Sabherwal et al., 2006). For Venkatesh \& Bala (2008), support and top management are interventions to be adopted in the pre-implementation of IT in order to minimize initial resistance and provide prior knowledge about the use of the system. In the public sector, top management plays a role in favouring the sharing of information between agencies, improving their quality, despite the difficulties imposed by the pressure of time and workload (Peel \& Rowley, 2010).

Considering the TAM factors, $\mathrm{PU}$ is the degree to which a person believes that the use of a specific system can improve job performance (Sabherwal et al., 2006). On the other hand, PEOU represents the ease of use perceived by the user, related to the degree to which a person believes that using a system would be free of effort. The expectation of effort to use systems is considered a determining factor which directly influences the use of TI (Venkatesh et al., 2003). Thus, even if IT is deemed to be useful, its adoption can be compromised if it requires a lot of user effort (Davis, 1989). For example, the difficulty that a user encounters when browsing the pages and menus of a system can cause frustration, anxiety, and resistance to use the system (Lapointe \& Rivard, 2005; Laumer et al., 2016).

Based on the TAM variables and Silva's model (2018), this article presents hypotheses described in the next section.

\section{Research Model and Hypotheses Development}

While acknowledge the robustness of IT adoption and use mainstream, studies continue analyzing (internal and external) critical factors of the organizations, helping to understand how users make decisions about systems adoption and use (Wu \& Lederer, 2009). Several previous studies indicate factors such as culture (Merchant, 2007), user satisfaction (Caldeira \& Ward, 2002; Zviran \& Erlich, 2003), quality of system (Sabherwal et al., 2006), training (Boothby et al., 2010), top-management support (Sharma \& Rai, 2003) and so on. Such factors have been analysed by theories of adoption in order to measure users' perception and behaviour towards information systems usage.

Thus, several models were also developed to investigate the attitudes, intentions, and behaviours related to the adoption of technologies in organizations such as Technology Acceptance Model (TAM) developed by Fred Davis in 1986; Unified Theory of Acceptance and Use of Technology -UTAUT) developed by de Venkatesh, Morris, Davis and Davis (2003); and the framework of Sabherwal et al. (2006). However, TAM has been considered the most influential and the most used in studies to address research concerns about IT adoption.

TAM emphasizes the mutual relationship between external variables that affect a user's acceptance of the technology (Davis, 1989) in different contexts. Based on this, studies have proved the positive effects of antecedents, such as training and top-management support on PU and PEOU (Gamage, 2019; Sabherwal et al., 2006). For instance, Caldeira and Ward (2002) found out the training influences 
effectiveness of the IS adoption since training enable users to use the system and help them to reduce resistance to changes as well. Thus, the more practice on a system, the more the user's perception towards ease of use (Shim \& Shim, 2019).

Similarly, top-management support can have a direct influence on PU because it motivates user participation and contributes to IT success in organizations (Sabherwal et al., 2006). Chan and Ngai (2007) consider that top-management support is a contingency factor that affects technology adoption. In organizations, people embrace technology because they are influenced by their leaders. This is often the case with people who are unfamiliar with the system and who come to believe in the experience of the leader or manager. The model by Sabherwal and colleagues (2006) explains that senior management is represented by the participation of executives favouring attitudes around the system, highlighting its direct influence on its use. However, despite the relevance of this factor, the authors have not confirmed its influence on PEOU. Likewise, Silva (2018) did not identify a significant relationship between such variables, although considered a critical success factor by several authors (Hochstein et al., 2005; Pollard \& Cater-Steel, 2009; Tan et al., 2007). Thus, the following hypotheses are raised:

H1. Training has a positive effect on the PU of EIS at UFCG

H2. Training has a positive effect on the PEOU of EIS at UFCG

H3. Top-management support has a positive effect on PU of the EIS at UFCG

H4. Top-management support has a positive effect on the PEOU of the EIS at UFCG

PEOU is defined as the degree to which a user believes that using a system will improve his performance at work. The TAM model recommends that PEOU has a positive influence on PU, because the easier it is to use a system, the greater the perception of its usefulness (Davis, 1989). Therefore, the following hypothesis is proposed:

H5. PEOU has a positive effect on the PU of EIS at UFCG

Regarding the perceived benefits from the use of EIS in public institutions, the literature (Silva, 2018) highlights some variables such as speed to perform activities, cost reduction, transparency, among others. For instance, savings of physical space due to the reduction of copies, paper, and toner are positive issues of the implementation of EIS (Nascimento, 2017). Silva (2018) argues that PEOU, has a significant influence on the perceived benefits. Thus, considering that PU is influenced by PEOU, we hypothesize that:

H6. PU has a positive effect on the perceived benefits from the EIS implementation at UFCG

H7. PEOU has a positive effect on the perceived benefits from the EIS implementation at UFCG

Figure 1 - Research Model

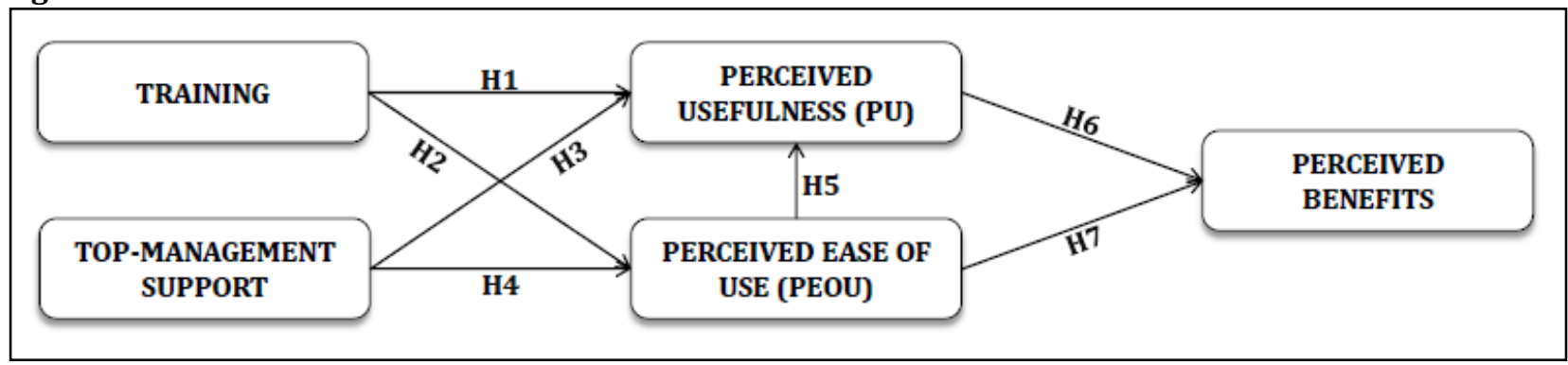

Source: Elaborated by authors (2020).

Based on these hypotheses, it proposes a research model (Figure 1) that predicts the influence of top-management support and training on perceived benefits by EIS's users at UFCG mediated by TAM antecedents such PU and PEOU. Since a high degree of awareness of these benefits can contribute to a more effective system adoption process.

\section{Research Methodology}

This current research used a positivist research approach, concentrating on quantitative data and providing an efficient way to measure perceptions of public employees from UFCG towards organiza- 
tional factors and system characteristics on the adoption of information systems in Public Administration. To evaluate the research model, it has used a survey like a strategy, structured on a five-point Likert scale, ranging from 1 to 5 (strongly disagree to strongly agree) to measure individual perceptions of the training process, top-management support, perceived ease of use, perceived usefulness and the influence of these factors on the perceived benefits of EIS.

The survey was based on the literature (Silva, 2018), using items validated and empirically tested. The validation process of the study was carried following qualitative operations along with three employees of the EIS management team from UFCG. Thus, the clarity, relevance, and representativeness of the items were analysed. The survey was carried out with employees (teachers and administrative technicians) from UFCG who have used EIS since its implementation. The tool has investigated the perception of these users towards training, top- management support, PU, PEOU, and perceived benefits.

Data were collected through an online questionnaire sent by the EIS support team via institutional email, addressed to all users registered in the system, belonging to the seven university campuses from UFCG. In addition, the instrument was disseminated on the official website of EIS, as well as on social networks. The universe of the research consists of 3.062 active employees, of which 1.634 are professors, and 1,428 are technical-administrative staff, distributed across seven UFCG campuses. Given the difficulty of face-to-face access to employees, we opted for non-probabilistic accessibility sampling, where the size of the sample was conditioned to the possibility of the operationalization of statistical tests. Thus, 305 valid questionnaires were collected, representing a significant sample for statistical operationalization.

Figure 2 - Conceptual definition of the constructs

\begin{tabular}{|c|c|c|}
\hline CONSTRUCT & DEFINITION & SOURCE \\
\hline TRAINING & $\begin{array}{l}\text { It represents the degree to which the organization } \\
\text { provides specific instruction to support the adop- } \\
\text { tion and diffusion of technology through courses, } \\
\text { manuals, etc. }\end{array}$ & $\begin{array}{l}\text { Sabherwal et al. } \\
\quad(2006) ; \\
\text { Bueno and Salm- } \\
\text { eron (2008). }\end{array}$ \\
\hline TOP-MANAGEMENT SUPPORT & $\begin{array}{l}\text { It represents the degree to which the top-manage- } \\
\text { ment actively supports the adoption of technology, } \\
\text { offering favorable support to its diffusion. }\end{array}$ & $\begin{array}{l}\text { Sabherwal et al. } \\
\qquad(2006) ; \\
\text { Bueno and Salm- } \\
\text { eron (2008). }\end{array}$ \\
\hline PERCEIVED USEFULNESS (PU) & $\begin{array}{l}\text { It refers to the degree to which a person believes } \\
\text { that using a particular system can improve job per- } \\
\text { formance. }\end{array}$ & Davis (1989). \\
\hline $\begin{array}{l}\text { PERCEIVED EASE OF USE } \\
\text { (PEOU) }\end{array}$ & $\begin{array}{l}\text { It represents the ease of use perceived by the user, } \\
\text { related to the degree to which a person believes } \\
\text { that using a system would be free of effort. It con- } \\
\text { cerns the ability of the software to enable the user } \\
\text { to easily achieve their system interaction goals. }\end{array}$ & $\begin{array}{l}\text { Sabherwal et al. } \\
\text { (2006); Davis } \\
\text { (1989). }\end{array}$ \\
\hline PERCEIVED BENEFITS & $\begin{array}{l}\text { It refers to the positive factors related to the imple- } \\
\text { mentation of systems in organizations, which in- } \\
\text { crease organizational performance before the pub- } \\
\text { lic, such as efficiency, effectiveness, reduction of } \\
\text { costs or errors, speed, access to information and } \\
\text { transparency. }\end{array}$ & $\begin{array}{l}\text { Bhuiyan (2011); } \\
\text { Heeks (2001); Kim } \\
\text { et al. (2009); } \\
\text { Monga (2008); } \\
\text { Silva (2018). }\end{array}$ \\
\hline
\end{tabular}

Source: Elaborated by authors (2020).

The steps to develop the measures were based on Davis (1989), Sabherwal et al. (2006), Bueno and Salmeron (2008), Silva (2018), Bhuiyan (2011), Heeks (2001), Kim et al. (2009) and Monga (2008). However, the domain of each construct was determined in Figure 2. The following statistical procedures and tests were performed: 1) database purification in order to eliminate outliers, making possible corrections and resulting in 292 valid questionnaires; 2) sample description; 3) reliability test applied to determine the internal consistency of the data along with the Cronbach's alpha, composite reliability (CR) and average variance extracted (AVE); 4) correlation analysis along the Pearson's correlation coefficient and discriminant validity; and 5) structural equation modelling (SEM) in order to test the relationships between variables of the model simultaneously. SEM was performed from the main components considering the 27 items of the questionnaire (see Appendix I). SEM was based on Lavaan package of R software version 4 . 


\section{Discussions}

In general, respondents have used EIS for eight months. From the 292 users, 140 are teachers, and 152 belong to the technical-administrative staff of the institution. From the respondents, $83 \%$ have a basic computer course, and only $3 \%$ claimed not to be used to using computer resources in the workplace. It is also highlighted that most respondents are male (58\%); aged from 31 to 40 years (39\%); and have completed postgraduate studies (77\%), indicating that they have a high level of qualification.

\subsection{Measurement Model Test and Tests of hypotheses}

In this study, the SEM was performed from the principal components considering the 27 items of the questionnaire applied to the UFCG civil servants (see Appendix I). During this phase, seven items were excluded due to the high values of kurtosis and skewness: be_efi_ati "EIS provides greater efficiency and effectiveness in carrying out activities related to administrative processes."; be_cel_pro "EIS provides more speed than the physical process (paper)."; be_red_cus "EIS reduces operating costs involved in activities related to administrative processes (e.g., paper, toner, offset ...)."; qua_tra_pub "EIS provides greater transparency and publicity in administrative processes than in the physical environment."; qu_ace_inf "EIS allows access to information about the administrative processes consulted by the user."; ut_uti_ati "EIS is useful in activities involving administrative processes."; and ut_mel_qua "EIS improves the quality of activities that involve administrative processes.".

Table 1 - Quality Values for SEM Model

\begin{tabular}{|c|c|c|c|c|c|}
\hline Constructs & Items & $\begin{array}{l}\text { Factorial } \\
\text { Loads }\end{array}$ & $\begin{array}{c}\text { Cronbach's } \\
\text { Alpha }\end{array}$ & $\underset{(>0.7)}{C R}$ & $\operatorname{AVE}(>0.5)$ \\
\hline \multirow{4}{*}{ TRAINING } & tr_tre_ade & 0.86 & \multirow{4}{*}{0.82} & \multirow{4}{*}{0.825} & \multirow{4}{*}{0.578} \\
\hline & tr_ace_tre & 0.84 & & & \\
\hline & tr_sup_tre & 0.67 & & & \\
\hline & tr_fer_tre & 0.55 & & & \\
\hline \multirow{4}{*}{$\begin{array}{l}\text { TOP-MANAGE- } \\
\text { MENT SUP- } \\
\text { PORT }\end{array}$} & ap_int_uso & 0.92 & \multirow{4}{*}{0.93} & \multirow{4}{*}{0.929} & \multirow{4}{*}{0.759} \\
\hline & ap_apo_impl & 0.92 & & & \\
\hline & ap_vis_cla & 0.87 & & & \\
\hline & ap_aju_uso & 0.79 & & & \\
\hline \multirow{3}{*}{$\begin{array}{l}\text { PERCEIVED } \\
\text { USEFULNESS } \\
\text { (PU) }\end{array}$} & ut_aum_pro & 0.70 & \multirow{3}{*}{0.93} & \multirow{3}{*}{0.872} & \multirow{3}{*}{0.712} \\
\hline & ut_sis_suc & 0.85 & & & \\
\hline & ut_sat_sis & 0.94 & & & \\
\hline \multirow{5}{*}{$\begin{array}{c}\text { PERCEIVED } \\
\text { EASE OF USE } \\
\text { (PEOU) }\end{array}$} & us_int_did & 0.88 & \multirow{5}{*}{0.87} & \multirow{5}{*}{0.927} & \multirow{5}{*}{0.709} \\
\hline & us_com_fun & 0.90 & & & \\
\hline & us_fac_abr & 0.89 & & & \\
\hline & us_doc_ext & 0.75 & & & \\
\hline & us_doc_int & 0.81 & & & \\
\hline \multirow{4}{*}{$\begin{array}{l}\text { PERCEIVED BE- } \\
\text { NEFITS }\end{array}$} & be_red_err & 0.69 & \multirow{4}{*}{0.81} & \multirow{4}{*}{0.791} & \multirow{4}{*}{0.539} \\
\hline & qu_proc_adm & 0.56 & & & \\
\hline & qu_bus_inf & 0.80 & & & \\
\hline & qu_dis_inf & 0.83 & & & \\
\hline
\end{tabular}

Source: Data extracted from R software (2020).

After excluding these 7 items, the final model grouped 20 questions loaded into five constructs. The Table 1 shows that the variables presented high factor scores, the lowest value being 0.55 . Reliability analysis of the construct was performed using Cronbach's alpha. The results show excellent reliability of the set of items for all constructs since the lowest index found was $0.81(>=0.6$, according to Hair et al., 2009). It is observed that the values of the composite reliability (CR) are adequate ( $\geq 0.7)$ and the average extracted variance (AVE) showed satisfactory values for all constructs $(\geq 0.5)$, as recommended 
by Hair et al. (2009), indicating that the model has adequate convergent validity.

The correlations identified between the latent variables can be found in Table 2. It is observed that, in all cases, except for the perceived benefits variable, which have a high correlation with the PU, the diagonal values (square root of the AVE of each construct) are more significant than all the crosscorrelations among constructs. In general, it suggests that the model has discriminatory validity (Chin, 1998).

Table 2 - Correlation of latent variables and discriminant validity

\begin{tabular}{lccccc}
\hline & TRAINING & $\begin{array}{c}\text { TOP-MANAGE- } \\
\text { MENT SUP- } \\
\text { PORT }\end{array}$ & $\begin{array}{c}\text { PERCEIVED } \\
\text { USEFULNESS }\end{array}$ & $\begin{array}{c}\text { PERCEIVED } \\
\text { EASE OF } \\
\text { USE }\end{array}$ & $\begin{array}{c}\text { PERCEIVED } \\
\text { BENEFITS }\end{array}$ \\
\hline $\begin{array}{l}\text { TRAINING } \\
\text { TOP-MANAGE- } \\
\text { MENT SUP- }\end{array}$ & 0.760 & 0.517 & 0.871 & & \\
$\begin{array}{l}\text { PORT } \\
\text { PERCEIVED }\end{array}$ & 0.574 & 0.463 & 0.843 & & \\
$\begin{array}{l}\text { USEFULNESS } \\
\text { PERCEIVED }\end{array}$ & 0.641 & 0.434 & 0.767 & 0.842 & \\
$\begin{array}{l}\text { EASE OF USE } \\
\text { PERCEIVED }\end{array}$ & 0.505 & 0.423 & 0.774 & 0.645 & 0.734 \\
BENEFITS & & & & & \\
\hline
\end{tabular}

Source: Data extracted from R software (2020).

Yet, the results of adjustment measures for the model are shown in Table 3. Based on three adjustment model, we found the model that contains appropriate adjustments. First, we evaluated the initial model considering all variables observed. Next, we dropped variables observed with high values of kurtosis and skewness and found the calibrated a simulated model in order to verify the well performance of the model. Thus, results of the simulated model indicated an excellent fit to the data $(\chi 2=$ $558.783, \mathrm{df}=162, \mathrm{p}<0.000, \chi 2 / \mathrm{df}=3.4 ; \mathrm{RMSEA}=0.092, \mathrm{CFI}=0.914, \mathrm{TLI}=0.899$ ) with values of adjustment that comply with the limits indicated in the literature.

Table 3 - Adjustment measures for the model

\begin{tabular}{|c|c|c|c|c|c|}
\hline Index Type & Index Indicator & $\begin{array}{l}\text { Initial Model } \\
\text { Result }\end{array}$ & $\begin{array}{c}\text { Calibrated } \\
\text { Model Result }\end{array}$ & $\begin{array}{c}\text { Simulated } \\
\text { Model Result }\end{array}$ & $\begin{array}{c}\text { Reference Va- } \\
\text { lue }\end{array}$ \\
\hline \multirow{6}{*}{$\begin{array}{l}\text { Absolute Ad- } \\
\text { justment }\end{array}$} & $\mathrm{X}^{2}$ - Chi-square & 1.298 .189 & 815.639 & 558.783 & p-value $>0.05$ \\
\hline & Degree of freedom (df) & 316.000 & 201.000 & 162.000 & Higher than one \\
\hline & $\begin{array}{l}\text { Normed Chi-square: } \\
\mathrm{X}^{2} / \mathrm{df}\end{array}$ & 4 & 4 & 3 & $\begin{array}{l}1 \text { and } 3: \text { good } \\
\text { Fit }>5=\text { bad }\end{array}$ \\
\hline & $\begin{array}{l}\text { Goodness-of-fit index } \\
\text { (GFI) }\end{array}$ & 0.720 & 0.778 & 0.830 & $\begin{array}{l}\geq 0.90 \\
(0 \text { e } 1)\end{array}$ \\
\hline & $\begin{array}{l}\text { Root Mean Square Resid- } \\
\text { ual (RMR) }\end{array}$ & 0.105 & 0.096 & 0.094 & $\leq 0.05$ \\
\hline & $\begin{array}{l}\text { Standardized Root Mean } \\
\text { Residual (SRMR) }\end{array}$ & 0.077 & 0.069 & 0.065 & $\geq 0.1$ \\
\hline \multirow{3}{*}{$\begin{array}{l}\text { Incremental } \\
\text { adjustment }\end{array}$} & Normed Fit Index (NFI) & 0.821 & 0.852 & 0.884 & $\geq 0.9$ \\
\hline & $\begin{array}{l}\text { Comparative Fit Index } \\
\text { (CFI) }\end{array}$ & 0.858 & 0.884 & 0.914 & $\begin{array}{c}\geq 0.9 \\
(0 \text { e } 1)\end{array}$ \\
\hline & Tucker Lewis index (TLI) & 0.842 & 0.866 & 0.899 & $(0$ e 1$)$ \\
\hline \multirow{3}{*}{$\begin{array}{l}\text { Parsimonious } \\
\text { adjustment }\end{array}$} & $\begin{array}{l}\text { Adjusted Goodness of Fit } \\
\text { Index (AGFI) }\end{array}$ & 0.664 & 0.720 & 0.780 & $\geq 0.9$ \\
\hline & $\begin{array}{l}\text { Parsimony Normed Fit } \\
\text { Index (PNFI) }\end{array}$ & 0.739 & 0.742 & 0.753 & $\begin{array}{l}\text { Biggest value: } \\
\text { best fit }\end{array}$ \\
\hline & $\begin{array}{l}\text { Parsimony Goodness-of- } \\
\text { fit index (PGFI) }\end{array}$ & 0.601 & 0.618 & 0.640 & $\begin{array}{c}\leq 0.67 \text { being } 0.5 \\
\text { a good fit }\end{array}$ \\
\hline $\begin{array}{l}\text { Population } \\
\text { adjustment }\end{array}$ & $\begin{array}{l}\text { Root Mean square error } \\
\text { of approximation } \\
\text { (RMSEA) }\end{array}$ & 0.103 & 0.102 & 0.092 & $<0.10$ \\
\hline
\end{tabular}

Source: Data extracted from R software (2020). 
Table 4 presents the results of regression analysis between variables training and top-management support and the dependent variables PU, PEOU, and perceived benefits. It was verified that the hypotheses $\mathrm{H} 2$, H3, H4, H5 e H6 were supported at a 5\% level of significance ( $<<0.05)$, while hypotheses H1 and H7 were rejected.

Table 4 - Summary of the results of the tested hypotheses

\begin{tabular}{lccc}
\hline \multicolumn{1}{c}{ HYPOTHESES } & Estimate & P-value & Result \\
\hline $\begin{array}{l}\text { H1: Training has a positive effect on the Perceived Usefulness of } \\
\text { the EIS at UFCG. }\end{array}$ & 0.098 & $0.403^{*}$ & $\begin{array}{c}\text { Not Sup- } \\
\text { ported }\end{array}$ \\
\hline $\begin{array}{l}\text { H2: Training has a positive effect on the Perceived Ease of Use of } \\
\text { the EIS at UFCG. }\end{array}$ & 0.828 & 0.000 & Supported \\
\hline $\begin{array}{l}\text { H3: Top-management support has a positive effect on the Per- } \\
\text { ceived Usefulness of the EIS at UFCG. }\end{array}$ & 0.260 & 0.004 & Supported \\
\hline $\begin{array}{l}\text { H4: Top-management support has a positive effect on the Per- } \\
\text { ceived Ease of Use of the EIS at UFCG. }\end{array}$ & 0.183 & 0.020 & Supported \\
\hline $\begin{array}{l}\text { H5: Perceived Ease of Use has a positive effect on the Perceived } \\
\text { Usefulness of the EIS at UFCG. }\end{array}$ & 1.168 & 0.000 & Supported \\
\hline $\begin{array}{l}\text { H6: Perceived Usefulness has a positive effect on the Perceived } \\
\text { Benefits from the EIS implementation at UFCG. }\end{array}$ & 0.973 & 0.000 & Supported \\
\hline $\begin{array}{l}\text { H7: Perceived Ease of Use has a positive effect on the Perceived } \\
\text { Benefits from the EIS implementation at UFCG. }\end{array}$ & -0.177 & $0.316^{*}$ & $\begin{array}{c}\text { Not Sup- } \\
\text { ported }\end{array}$ \\
\hline
\end{tabular}

Source: Data extracted from R software (2020).

Note: * Not Significant at $5 \%$ level.

Curiously, training $(\beta=0.098 ; p \geq 0.05$ ) has no significant effect on the PU of EIS, ratifying the conclusion of Ramkumar and Jenamani (2015). A possible evidence proving that it occurs related to the need to transmit the value of the system during the training process before implementing it. It can provide motivation and a better understanding about the benefits of the system for user's tasks (Gamage, 2019). Likely, users of SEI did not get enough knowledge about how SEI reduce the user's effort to perform the activities in a more effective way. On the other hand, training $(\beta=0.828 ; p \leq 0.05)$ has a positive and significant effect on PEOU. The promotion of adequate training positively influences the user's perception of the ease of use, corroborating the findings of the literature (Davis, 1989; Gamage, 2019; Sabherwal et al., 2006; Silva, 2018).

Top-management support positively impacts users' perceptions of system usefulness $(\beta=0.260$; $p \leq 0.05)$ and perceptions of ease of use $(\beta=0.183$; $p \leq 0.05)$. Thus, it is inferred that the more involvement of senior management in the EIS adoption process, providing support, help, and resources necessary for the use of the system, the more the user's perception that the system is useful and easy. Different from the findings of Sabherwal et al. (2006) and Silva (2018), our results reinforce the importance of the role of top-management as a critical factor for the successful implementation of IT in organisations. These results converge with research provided in other studies (Hochstein et al., 2005; Pollard \& CaterSteel, 2009; Tan et al., 2007).

As foreseen in the original TAM (Davis et al., 1989), PEOU has a positive and robust effect on the PU regarding perceptions of EIS' user $(\beta=1,168 ; p \leq 0.05)$. It indicates that if EIS is perceived as easy to operate; consequently, it can be considered useful because users would perceive less effort to perform their activities through system usage. It means that the design of the system is an important factor to be considered before implementing it.

Yet, there is a positive influence between $\mathrm{PU}(\beta=0.973 ; \mathrm{p} \leq 0.05)$ and the benefits perceived by users. It indicates the more useful is the system, the more the user's ability to see the benefits of using it. Conversely, PEOU has not a positive effect on the users' perception of the benefits of the EIS $(\beta=-$ $0.177 ; \mathrm{p} \geq 0.05$ ). In particular, the descriptive statistics analysis confirmed that the PEOU was poorly rated by its users due to the inefficiency of training provision and top-management support, which directly reflects the perceived benefits which facilitate the system adoption. Figure 3 presents the nomological structure of the research model.

Thus, it can be inferred that the more training the users have received, the more perception of the usability of this system, contributing to improving their understanding of the design, terms, and functionalities of the EIS, as well as reducing the level of difficulty in performing tasks related to administrative processes. However, it is interesting to observe the different effects of training and the top- 
management support on PEOU. It is clear that training has a stronger influence on the user's perception towards the ease of use of EIS. It seems reasonable once that users have to receive knowledge about how the system can operate efficiently to perform their activities during the training process. At the same time, the top-management can only stimulate its use and provide resources for the implementation of the system.

Figure 3 - Nomological structure of the research model

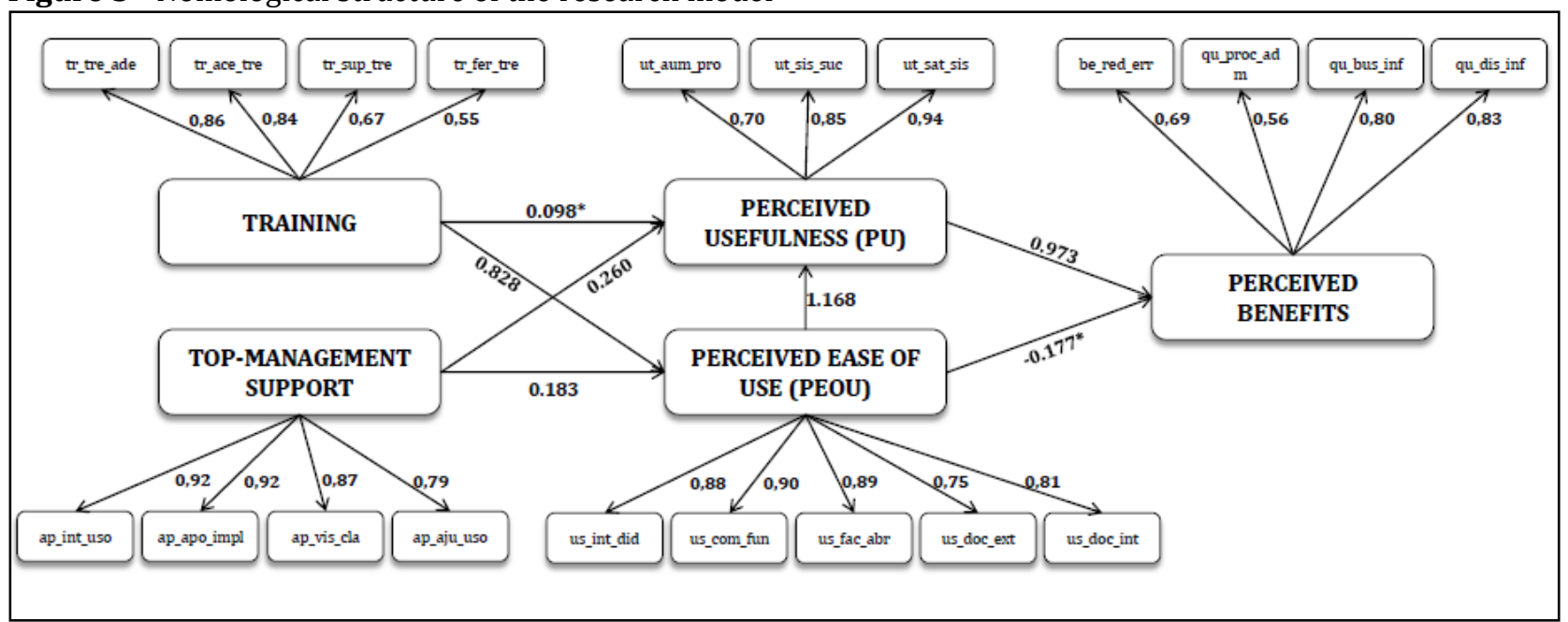

Source: Research data, (2020).

Note: * Not Significant at $5 \%$ level.

\section{Conclusions}

This research aimed to analyze the influence of organizational factors in the adoption of the information system at UFCG. To do so, it built a research model to investigate the influence of top-management support and training on perceived benefits by EIS's users at UFCG mediated by TAM antecedents such PU and PEOU. The research model test reveals that training users to use EIS has significantly impacted the way they perceive how easy it is to use the EIS. Nevertheless, the useful perception was committed during the training, since users did not perceive enough usefulness while training process before the implementation of the EIS. It is noted that it is in the training process that users can be aware of the resources and tools that the system offers to make their work easier and more efficient. This understanding can contribute to ensure a better use of available resources in the system, avoiding its underutilization.

Concerning the top-management support for the adoption of the system, users perceive the interest and support of the immediate managers about the implementation of the EIS. This perception positively influenced the understanding of the system's usefulness and easy use as well. However, users believe that the lack of a clear view on the use of the EIS by top management has made it challenging to provide the necessary resources for effective adoption. Thus, top-management support is an essential factor for the effective use of the system. An example of this is to be aware that it is necessary to invest in resources that guarantee effectiveness in the implementation, maintenance, and training of employees so that they assimilate the technology and make effective use of it.

Interestingly, the results state that the training was not effective enough to transmit to users the knowledge that EIS can be useful for performing their activities. Perceived usefulness was reinforced by top-management support and PU. However, the effect that training could have on PU likely should be strong if users receive appropriate knowledge about how a system can reduce efforts to perform activities, not only how to use it. Despite top-management support is relevant to the system acceptance process, such support can only stimulate in a certain degree, the user's perception towards the system's usability and ease of use of the system. Nevertheless, findings reveal PU as a mediating factor of training, and top-management did not compromised the degree of comprehension of the system's benefits by users.

Curiously, PU, and perceived benefits did not reflect the dimensional structure proposed by the measurement model. Although there is a difference in amplitude between the concept of both constructs, where PU offers a dimensional structure at the level of the individual and benefit offers at the 
organizational level, the results indicate that the individuals perceived both constructs as similar. It sounds controversial once PEOU has not influence in benefits of the system for the organization, but it has an influence in PU.

In summary, the results of this study reinforce the importance of training and support from senior management in the process of adopting technologies in the public sector. Thus, it is evident that factors have a direct influence on the perception of the easy of the system. This study also confirmed the significant positive influence by the usefulness of the system on the benefits perceived by EIS users at UFCG. Therefore, the higher the perception of the usefulness of a system, the higher the user's ability to grasp the benefits of its use at an organizational level.

This research has theoretical and practical implications. First, the theoretical contributions are that research offers an instrument that can be replicated for other studies in order to apply for public institutions to assess the level of adoption of information systems. A relevant theoretical contribution is that the results of measurements for PU and benefits reinforce the need for a better understanding towards concepts and variables of both constructs. Such a situation opens up new opportunities for theory to understand such constructs in a mandatory context of IT. Second, the practical contributions are managerial, providing an understanding of the factors that can influence the adoption of EIS, consequently, contributing to give a more favourable environment for its acceptance. Thus, managers will be able to pay more attention to more effective training programs and provide the necessary resources for the implementation and use of EIS, as well as to make users aware of the importance of the system for their work activities.

This study has two limitations. First, the study did not consider the external community's perceptions towards use of the EIS, for example, researchers and professors of other institutions who should use the system when invited to participate of some activities in collaboration with UFCG. It has limited the results only from an internal view since it has considered only the opinion of the employees from UFCG. Second, although the validation of the questionnaire with specialists was considered sufficient, this study recognizes that it would be feasible to carry out a pre-test with potential respondents to reinforce the process of validating the questionnaire. Thus, it is recommended to apply the survey to include the pre-test as a validation step.

Finally, for future studies, it suggests for researchers to analyse the influence of potential factors that inhibit the adoption of systems that are intrinsic to the public sector, such as the scarcity of resources and personnel, budget restrictions, change of government, and volatility of public strategies and policies. Besides, this study also suggests scholars explore the perception of society regarding the use of information systems implemented by the Public Administration with the participation of the external public in government decisions and actions. Such an investigation will allow a more holistic view of the adoption of these technological innovations in Public Administration.

\section{References}

Alreemy, Z., Chang, V., Walters, R., \& Wills, G. (2016). Critical success factors (CSFs) for information technology governance (ITG). International Journal of Information Management, 36(6), 907-916.

Alsoub, R. K., Alrawashdeh, T. A., \& Althunibat, A. (2018). User acceptance criteria for enterprise resource planning software systems. International Journal Of Innovative Computing Information And Control, 14(1), 297-307.

Andion, C. (2012). Por uma nova interpretação das mudanças de paradigma na administração pública. Cadernos Ebape. BR, 10(1), 1-19.

Avanzi, D. da S., Foggiatto, A., dos Santos, V. A., Deschamps, F., \& Loures, E. de F. R. (2017). A framework for interoperability assessment in crisis management. Journal of Industrial Information Integration, 5, 26-38.

Bertot, C., Jaeger, P. T., \& Grimes, J. M. (2012). Promoting transparency and accountability through ICTs, social media, and collaborative e-government. Transforming government: people, process and policy, 6(178-91).

Bhattacherjee, A., \& Premkumar, G. (2004). Understanding Changes in Belief and Attitude toward Information Technology Usage: A Theoretical Model and Longitudinal Test. MIS Quarterly, 28(2), 229254. JSTOR. https://doi.org/10.2307/25148634

Bhuiyan, S. H. (2011). Modernizing Bangladesh public administration through e-governance: Benefits 
and challenges. Government Information Quarterly, 28(1), 54-65.

Boothby, D., Dufour, A., \& Tang, J. (2010). Technology adoption, training and productivity performance. Research Policy, 39(5), 650-661.

Borins, S. (2001). Encouraging innovation in the public sector. Journal of intellectual capital, 2(3), 310319. https://doi.org/10.1108/14691930110400128

Bresser-Pereira, L. C. (2006). Da administração pública burocrática à gerencial. In Reforma do Estado e administração pública gerencial. (7 ed.). FGV.

Bueno, S., \& Salmeron, J. L. (2008). TAM-based success modeling in ERP. Interacting with computers, 20(6), 515-523.

Caldeira, M. M., \& Ward, J. M. (2002). Understanding the successful adoption and use of IS/IT in SMEs: An explanation from Portuguese manufacturing industries. Information Systems Journal, 12(2), 121152.

Chan, S. C., \& Ngai, E. W. (2007). A qualitative study of information technology adoption: How ten organizations adopted Web-based training. Information Systems Journal, 17(3), 289-315.

Chin, W. W. (1998). The partial least squares approach to structural equation modeling. Modern methods for business research, 295(2), 295-336.

Cordella, A., \& Paletti, A. (2818). ICTs and value creation in public sector: Manufacturing logic vs service logic. Information Polity, 23(2), 125-141.

Cunha, M. X. C., Souza Junior, M. F., Dornelas, J. S., \& Maiad, C. F. M. (2011). Análise da Implantação dos Sistemas de Informação em uma Instituição Federal de Ensino de Alagoas à Luz da Teoria Institucional. Revista de Administração, Contabilidade e Economia da Fundace, 2(2), 1-16.

Davis, F. D. (1989). Perceived usefulness, perceived ease of use, and user acceptance of information technology. MIS quarterly, 319-340.

Davis, F. D., Bagozzi, R. P., \& Warshaw, P. R. (1989). User acceptance of computer technology: A comparison of two theoretical models. Management science, 35(8), 982-1003.

Gamage, T. C. (2019). Determinants of Cloud Computing Adoption among SMEs in Sri Lanka: A Meta Theoretical Framework. International Journal of Asian Social Science, 9(2), 189-203.

Hair, J. F., Black, W. C., Babin, B. J., Anderson, R. E., \& Tatham, R. L. (2009). Análise multivariada de dados. Bookman Editora.

Heeks, R. (2001). Understanding e-governance for development. The University of Manchester. Institute for Development, Policy and Management Information, Systems, Technology and Government: Working Papers Series, 11.

Hochstein, A., Zarnekow, R., \& Brenner, W. (2005). ITIL as common practice reference model for IT service management: Formal assessment and implications for practice. 2005 IEEE International Conference on e-Technology, e-Commerce and e-Service, 704-710.

Hsieh, C., Tien, S., Hwang, W., \& Chung, N. (2011). Building the Crisis Prevention Model for the Innovation Development of Green Marketing Take the HOTAIMOTOR as Example. Sci Res Publ, Inc-Srp.

Hussein, L. A., Baharudin, A. S., Jayaraman, K., \& Kiumarsi, S. (2019). B2B e-commerce technology factors with mediating effect perceived usefulness in Jordanian manufacturing SMES. Journal of Engineering Science and Technology, 14(1), 411-429.

Kamal, M. M. (2006). IT innovation adoption in the government sector: Identifying the critical success factors. Journal of Enterprise Information Management.

Kim, H.-W., \& Kankanhalli, A. (2009). Investigating user resistance to information systems implementation: A status quo bias perspective. MIS quarterly, 567-582.

Kim, S., Kim, H. J., \& Lee, H. (2009). An institutional analysis of an e-government system for anti-corruption: The case of OPEN. Government Information Quarterly, 26(1), 42-50.

Koch, P., \& Hauknes, J. (2005). Innovation in the public sector, publin report, no. D 20. J. Hauknes.Oslo: NIFU STEP.

Lapointe, L., \& Rivard, S. (2005). A multilevel model of resistance to information technology implementation. MIS quarterly, 461-491.

Laumer, S., Maier, C., Eckhardt, A., \& Weitzel, T. (2016). Work routines as an object of resistance during information systems implementations: Theoretical foundation and empirical evidence. European Journal of Information Systems, 25(4), 317-343. 
Liddle, J. (2013). Innovation in the public sector: Linking capacity and leadership-edited by Victor Bekkers, Jurian Edelenbos and Bram Steijn. Public Administration, 91(2), 511-513.

Luciano, Edimara M., Wiedenhöft, G. C., Macadar, M. A., \& Pereira, G. V. (2017). Discussing and Conceiving an Information and Technology Governance Model in Public Organizations. In Information Technology Governance in Public Organizations (p. 3-26). Springer.

Luciano, Edimara Mezzomo, Wiedenhöft, G. C., \& Santos, F. P. dos. (2018). Promoting social participation through digital governance: Identifying barriers in the brazilian public administration. Proceedings of the 19th Annual International Conference on Digital Government Research: Governance in the Data Age, 1-9.

Mayne, J., \& Zapico-Goñi, E. (2017). Effective performance monitoring: A necessary condition for public sector reform. In Monitoring Performance in the Public Sector (p. 3-30). Routledge.

Merchant, S. (2007). Exploring the influence of cultural values on the acceptance of information technology: An application of the technology acceptance model. Informing Science: International Journal of an Emerging Transdiscipline, 4(1), 431-443.

Monga, A. (2008). E-government in India: Opportunities and challenges. Journal of Administration and Governance, 3(2), 52-61.

Moussa, M., McMurray, A., \& Muenjohn, N. (2018). A conceptual framework of the factors influencing innovation in public sector organizations. The Journal of Developing Areas, 52(3), 231-240.

Napitupulu, D., \& Sensuse, D. I. (2014). The critical success factors study for e-Government implementation. International Journal of Computer Applications, 89(16), 23-32.

Nascimento, P. R. D. S. (2017). Nascimento, P. R. D. S. (2017). Impactos da implantação do Sistema Eletrônico de Informação (SEI): Estudo de caso da Universidade de Brasília. [Dissertação de Mestrado]. Faculdade de Economia, Administração e Contabilidade - FACE/PPGE. Brasília - DF.

Oliveira, L. C. P., Faleiros, S. M., \& Diniz, E. H. (2015). Sistemas de informação em políticas sociais descentralizadas: Uma análise sobre a coordenação federativa e práticas de gestão. , 49(1), 23-46. Revista de Administração Pública-RAP, 49(1), 23-46.

Osborne, S. P. (2010). Delivering Public Services: Time for a new theory? Public Management Review, 12(1), 1-10. https://doi.org/10.1080/14719030903495232

Peel, M., \& Rowley, J. (2010). Information sharing practice in multi-agency working. Aslib proceedings: New information perspectives, 62, 11-28.

Pollard, C., \& Cater-Steel, A. (2009). Justifications, strategies, and critical success factors in successful ITIL implementations in US and Australian companies: An exploratory study. Information systems management, 26(2), 164-175.

Ramkumar, M., \& Jenamani, M. (2015). Organizational buyers' acceptance of electronic procurement services-An empirical investigation in Indian firms. Service Science, 7(4), 272-293.

Reis, A. L. N., \& Neto, J. S. (2019). Critical success factors in implementing information technology governance in federal public administration. Revista Do Servico Publico, 70(4), 609-630.

Rizzuto, T. E., Schwarz, A., \& Schwarz, C. (2014). Toward a deeper understanding of IT adoption: A multilevel analysis. Information \& Management, 51(4), 479-487.

Rusu, L., \& Viscusi, G. (2017). Information Technology Governance in Public Organizations: Theory and Practice (Vol. 38). Springer.

Saab, F., de Souza Bermejo, P. H., Garcia, G. C., Pereira, J. S., \& e Silva, S. de A. M. (2018). Does public consultation encourage social participation? Journal of Enterprise Information Management.

Saab, F., Lira, W. R. C., Alves, C. de S., Bermejo, P. H. de S., \& Borges, G. H. A. (2019). Public Management and Technology: How Can e-Government Strategies Contribute to Greater Efficiency in Public Expenditures? Third International Congress on Information and Communication Technology, 457-470.

Sabherwal, R., Jeyaraj, A., \& Chowa, C. (2006). Information system success: Individual and organizational determinants. Management Science, 52(12), 1849-1864.

Scupola, A., \& Zanfei, A. (2016). Governance and innovation in public sector services: The case of the digital library. Government Information Quarterly, 33(2), 237-249.

Secchi, L. (2009). Modelos organizacionais e reformas da administração pública. Revista de Administração Pública, 43(2), 347-369.

Sharma, S., \& Rai, A. (2003). An assessment of the relationship between ISD leadership characteristics and IS innovation adoption in organizations. Information \& Management, 40(5), 391-401. 
Shim, S. J., \& Shim, M. K. (2019). Effects of user perceptions of SAP ERP system on user learning and skills. Journal of Computing in Higher Education, 1-16.

Silva, R. B. da. (2018). Processo eletrônico no Brasil: Um estudo sobre facilitadores, inibidores e benefícios da sua adoção. Universidade Federal do Rio Grande.

Sinni, G. (2017). Participatory Design for Public Services. Innovation in Public Administration. The Design Journal, 20(sup1), S3368-S3379.

Tan, W.-G., Cater-Steel, A., Toleman, M., \& Seaniger, R. (2007). Implementing centralised IT service management: Drawing lessons from the public sector. ACIS 2007 Proceedings, 94.

Van Ryzin, G. G. (2015). Service Quality, Administrative Process, and Citizens' Evaluation of Local Government in the US. Public Management Review, 17(3), 425-442.

https://doi.org/10.1080/14719037.2013.841456

Venkatesh, V., \& Bala, H. (2008). Technology acceptance model 3 and a research agenda on interventions. Decision sciences, 39(2), 273-315.

Venkatesh, V., Morris, M. G., Davis, G. B., \& Davis, F. D. (2003). User acceptance of information technology: Toward a unified view. MIS quarterly, 425-478.

Von Haldenwang, C. (2004). Electronic government (e-government) and development. The European journal of development research, 16(2), 417-432.

$\mathrm{Wu}$, J., \& Lederer, A. (2009). A meta-analysis of the role of environment-based voluntariness in information technology acceptance. Mis Quarterly, 419-432.

Young, R., \& Poon, S. (2013). Top management support-Almost always necessary and sometimes sufficient for success: Findings from a fuzzy set analysis. International journal of project management, 31(7), 943-957.

Zviran, M., \& Erlich, Z. (2003). Measuring IS user satisfaction: Review and implications. Communications of the Association for Information Systems, 12(1), 5. 
Appendix I - Survey Construct Items

\begin{tabular}{|c|c|c|c|}
\hline$*$ & Itens & Constructs & Reference \\
\hline \multicolumn{4}{|c|}{ TRAINING } \\
\hline & tr_tre_ade & I have received adequate (and quality) training to use the EIS. & \multirow{4}{*}{$\begin{array}{l}\text { Adapted from } \\
\text { Silva (2018) }\end{array}$} \\
\hline & tr_ace_tre & Access to EIS training is facilitated by the institution. & \\
\hline & tr_sup_tre & $\begin{array}{l}\text { I am aware that EIS support provides training tools (tutorial videos and training } \\
\text { environment) on its page. }\end{array}$ & \\
\hline & tr_fer_tre & Frequently access the training tools available on the EIS page. & \\
\hline \multicolumn{4}{|c|}{ TOP-MANAGEMENT SUPPORT } \\
\hline & ap_int_uso & The immediate head of my work sector is interested in using EIS. & \multirow{4}{*}{$\begin{array}{l}\text { Adapted from } \\
\text { Silva (2018) }\end{array}$} \\
\hline & ap_apo_impl & The immediate head of my work sector has supported the implementation of EIS. & \\
\hline & ap_vis_cla & The immediate head of my work sector has a clear view of the use of EIS. & \\
\hline & ap_aju_uso & $\begin{array}{l}\text { The immediate head of my work sector has provided the help and resources } \\
\text { needed to use the EIS. }\end{array}$ & \\
\hline \multicolumn{4}{|c|}{ PERCEIVED USEFULNESS (PU) } \\
\hline \multirow[t]{2}{*}{$\mathrm{x}$} & ut_uti_ati & EIS it is useful in activities involving administrative processes. & \multirow{5}{*}{$\begin{array}{l}\text { Adapted from } \\
\text { Silva (2018) }\end{array}$} \\
\hline & ut_aum_pro & EIS increases my productivity in activities that involve administrative processes. & \\
\hline \multirow[t]{3}{*}{$\mathrm{x}$} & ut_mel_qua & EIS improves the quality of activities that involve administrative processes. & \\
\hline & ut_sis_suc & EIS it is a successful system, and its use is easy and didactic. & \\
\hline & ut_sat_sis & I am satisfied with EIS. & \\
\hline \multicolumn{4}{|c|}{ PERCEIVED EASE OF USE (PEOU) } \\
\hline & us_int_did & EIS has a didactic interface, with clear and objective functions. & \multirow{5}{*}{$\begin{array}{l}\text { Adapted from } \\
\text { Silva (2018) }\end{array}$} \\
\hline & us_com_fun & $\begin{array}{l}\text { The terms used to indicate the commands of the functions in the EIS are clear and } \\
\text { self-explanatory. }\end{array}$ & \\
\hline & us_fac_abr & $\begin{array}{l}\text { I felt easy when opening a process in EIS because the chaining of actions is simple } \\
\text { and dynamic. }\end{array}$ & \\
\hline & us_doc_ext & $\begin{array}{l}\text { Inserting external documents (PDF, for example) into a process generated by EIS } \\
\text { is a simple task. }\end{array}$ & \\
\hline & us_doc_int & $\begin{array}{l}\text { The insertion of internal documents (orders and opinions, for example) in a pro- } \\
\text { cess generated by the EIS is a simple task. }\end{array}$ & \\
\hline \multicolumn{4}{|c|}{ PERCEIVED BENEFITS } \\
\hline \multirow[t]{2}{*}{$\mathrm{x}$} & be_efi_ati & $\begin{array}{l}\text { EIS provides greater efficiency and effectiveness in carrying out activities related } \\
\text { to administrative processes. }\end{array}$ & \multirow{9}{*}{$\begin{array}{l}\text { Adapted from } \\
\text { Silva (2018) }\end{array}$} \\
\hline & be_red_err & $\begin{array}{l}\text { EIS reduces the occurrence of errors in carrying out activities related to adminis- } \\
\text { trative processes. }\end{array}$ & \\
\hline $\mathrm{x}$ & be_cel_pro & The EIS provides more speed than the physical process (paper). & \\
\hline $\mathrm{x}$ & be_red_cus & $\begin{array}{l}\text { EIS reduces operating costs involved in activities related to administrative pro- } \\
\text { cesses (e.g. paper, toner, travel ...). }\end{array}$ & \\
\hline & qu_proc_adm & $\begin{array}{l}\text { EIS facilitates access to administrative processes without confidentiality re- } \\
\text { strictions. }\end{array}$ & \\
\hline $\mathrm{x}$ & qu_tra_pub & $\begin{array}{l}\text { EIS provides greater transparency and publicity in administrative processes than } \\
\text { in the physical environment. }\end{array}$ & \\
\hline \multirow[t]{3}{*}{$\mathrm{x}$} & qu_ace_inf & $\begin{array}{l}\text { EIS allows access to information about the administrative processes consulted by } \\
\text { the user. }\end{array}$ & \\
\hline & qu_bus_inf & EIS's information search tools are tailored to the user's needs. & \\
\hline & qu_dis_inf & EIS allows distributing information among interested sectors/users. & \\
\hline
\end{tabular}

Source: Research data (2019).

Note: *Items marked with an $\mathrm{x}$ have been excluded from the final model 